\title{
Variation in alpha radioactivity of plants with the use of different fertilizers and radon measurement in fertilized soil samples
}

\author{
Pooja Chauhan ${ }^{*}$ and Rishi Pal Chauhan
}

\begin{abstract}
Background: People are exposed to ionizing radin from the radionuclides that are present in different types of natural sources, of which phosphate fertilizer is one of the most important sources. Fertilizers are commonly used in agricultural field worldwide to enhance the crop yield.

Materials and methods: In the present investigation, a control study was carried out on the lady's finger plants grown in earthen pots. To observe the effect of fertilizers their equal amounts were added to the soil just before the plantation. The alpha track densities were measured using solid state nuclear track detectors (SSNTDs), a sensitive detector for alpha particles.

Results: The measured alpha track densities $\left(\mathrm{cm}^{-2} \mathrm{~d}^{-1}\right)$ in lady's finger plants on top and bottom face of leaves after 30,50 and 70 days of plantation varied from $49 \pm 11$ to $206 \pm 2.6,49 \pm 16$ to $248 \pm 16$ and $57 \pm 8.5$ to $265 \pm 32$ respectively in various leaf samples.

Conclusions: The alpha track densities were found to vary with nature of fertilizers added to the soil and an increase was also observed with time. The alpha track densities were also measured in soil samples mixed with different fertilizers. The radon exhalation rates in various soil samples and soil to plant transfer factor (TF) of alpha tracks were also calculated.
\end{abstract}

Keywords: Radioactivity, Soil, Fertilizer, Plants, Alpha track density, Radon concentration

\section{Introduction}

Natural ionizing radiation is emitted as a result of spontaneous nuclear transformations of unstable radionuclides naturally occurring in the earth's crust (i.e. terrestrial origin) as well as those coming from outer space into the atmosphere (i.e. extraterrestrial origin) [1]. Natural radioactive materials under certain conditions can reach hazardous radiological levels. So, it is felt necessary to study the natural radioactivity in soil to assess the dose to the population in order to know the health risks and to have a baseline for future changes in the environmental radioactivity in human activities [2]. The basic component of our life support system is considered to be in the soil, water, plants and air. These environmental components contain measurable amount of radioactivity. The specific

\footnotetext{
* Correspondence: mpoojarana@gmail.com

Department of Physics, National Institute of Technology, Kurukshetra-136119,
} India

\section{Biomed Central}

(c) 2014 Chauhan and Chauhan; licensee BioMed Central Ltd. This is an Open Access article distributed under the terms of the Creative Commons Attribution License (http://creativecommons.org/licenses/by/2.0), which permits unrestricted use, distribution, and reproduction in any medium, provided the original work is properly credited. metabolic character of the plant species may lead to accumulation of radio-nuclides in their organs which may further depend upon the physico-chemical characteristics of the soil. Therefore, there may be increased risk to human population via food chain.

The radioactivity from the phosphate ore was not grossly affected by processing during fertilizer production. They are therefore likely to be transferred to the plants when applied to them [3]. According to the United Nations Scientific Committee on Effects of Atomic Radiation report [4], the greatest contribution to mankind's exposure comes from natural background radiation [5]. The study of natural radioactivity is usually done in order to gain the information about the present levels of harmful pollutants discharged to the environment itself or in the living creatures. It is also important to understand the behavior of natural radionuclides in the environment, because such information can be used as the associated 
parameter values for the radiological assessments [6]. The soil radioactivity is usually important for the purposes of establishing baseline data for the future radiation impact assessment, radiation protection and exploration [7].

The fertilizers are essential in agriculture as they supply nutrients to the farming fields. The fertilizers used for plantation contain different elements including some natural radionuclides with their daughter decay products. Fertilizer use is a key factor for increasing agricultural production in India and its utilization has increased rapidly in the last four decades, mainly due to adoption of high yielding and expanding nutrient responsive cultivated land in large parts of the country. Phosphate rocks are the starting materials for the production of all phosphate fertilizers. Soil and fertilizers consists of naturally occurring radionuclides with their daughter decay products. Relatively large concentrations of natural radionuclides present in phosphate fertilizers contaminate the environment and agricultural lands during cultivation [8]. Fertilizers are considered as technologically enhanced natural radiation, which increase the environmental uranium and partially thorium concentrations in the environment [9]. The primary sources of elements from the environment to plants are: air, water and the soil [10]. The radionuclides present in the environment transfer to plants through (i) uptake from soil through roots, and (ii) direct absorption through aerial parts of the plants. Presence of radioactivity in plant organs has been reviewed by various workers $[11,12]$. There are two major pathways for human exposure to soil contamination: soil-plant-human (food chain pathway) and soil-human (incidental soil ingestion) pathways. Migration and accumulation of contaminants in the soil-plant system is complex, and assessment models commonly utilize a soil-plant concentration ratio, referred to as a transfer factor (TF), to estimate the transportation of radionuclides through the food chain. This ratio describes the amount of radionuclide expected to enter a plant from soil [13]. The study of natural radioactivity in plants and associated radiation exposure through the specific food materials is an important study. Plant roots are naturally associated with microorganisms, and these associations can have direct or indirect effects on the mobility, availability and acquisition of elements by plants. There are different kinds of vegetables which may be roots, stems, leaves, fruits or seeds [14]. The radiological impact of the use of fertilizers in soil is due to the internal irradiation of the lung by the alpha particles, short lived radon-thoron progeny and the external irradiation of the body by gamma rays emitted from the radionuclides. Radon is carcinogenic to humans and responsible for main natural radiation exposure to human being [15-17].

In the present work, the estimation of alpha activity in leaves of lady's finger plants grown using different types of fertilizers like cow dung manure (CDM), DAP (Diammonium Phosphate), NPK (nitrogen, phosphorus and potassium), single super phosphate (SSP), potash $(\mathrm{PF})$, zinc sulphate $\left(\mathrm{ZnSO}_{4}\right)$, urea (URA), and organic fertilizer (OF) in same amounts before the plantation of the seedlings, has been made and reported. Lady's Finger with botanical name Abelmoschus esculentus (Linn) Moench, belongs to Malvaceae family. The present study is helpful not only for the assessment of radiation environment but also to assess the food safety due to the internal radiation.

\section{Materials and methods \\ Track etch technique}

The tracks etch technique which is the simplest, economical, feasible and an efficient passive method has been used to determine alpha activity in plants of lady's finger (Citrullus vul; garis Schard). The control study on lady's finger plants was carried out during the summer season (April-June 2013) suitable for its cultivation in India. In the present control study plants (2 samples each) were grown in earthen pots having equal amounts of (12 kg) of same type of soil. Equal amounts (30 gm) of fertilizers; cow dung manure (CDM), Diammonium Phosphate (DAP), Nitrogen, phosphorus and potassium

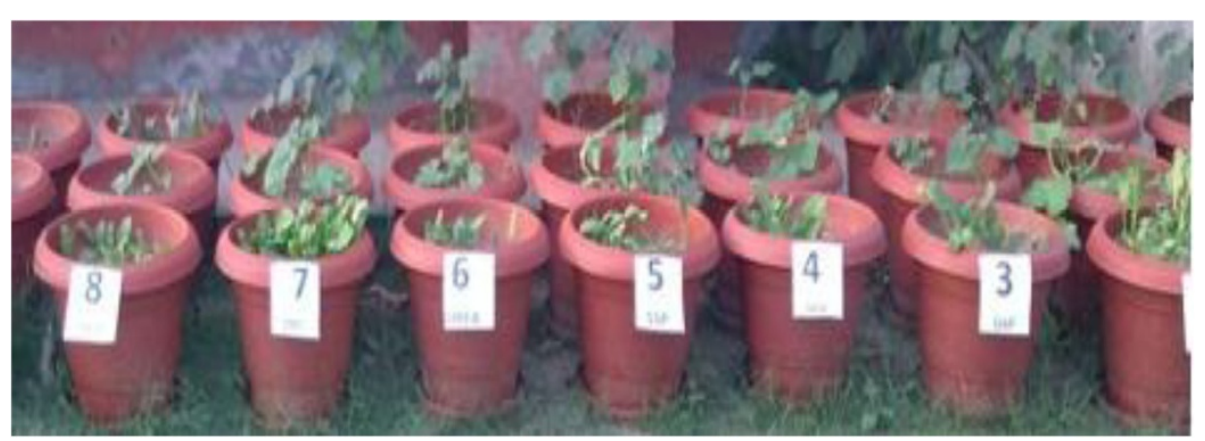

Figure 1 Photograph of the plants grown using different fertilizers under control study. 


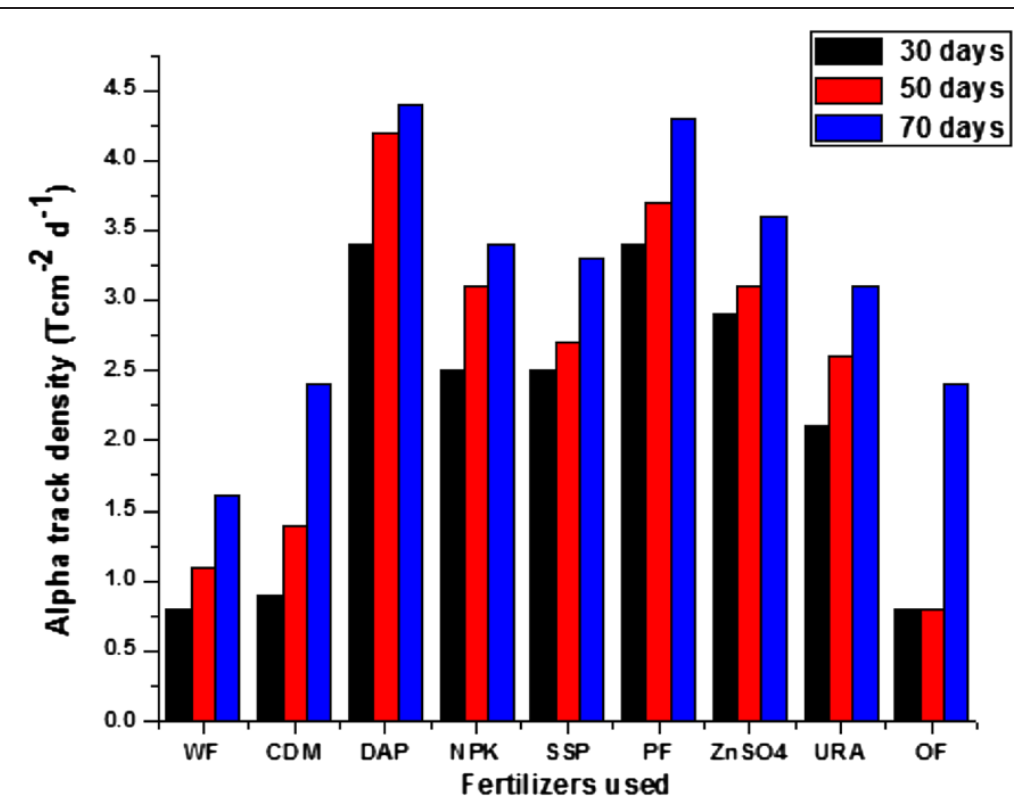

Figure 2 Variation in alpha track densities with different fertilizers used in Lady's finger plants after 30, 50 and 70 days of plantation.

(NPK), single super phosphate (SSP), potash (PF), zinc sulphate $\left(\mathrm{ZnSO}_{4}\right)$, urea (URA), and organic fertilizer (OF) were added to the soil during the plantation of the seeds of plants in the pots. The growth of plants in all the cases was also recorded at regular intervals of time as shown in (Figure 1). In other part of the study, the samples of complete plants were taken and dried, plastic track detectors

Table 1 Alpha track densities measured in the leaves of lady's finger plants after 30 days of plantation

\begin{tabular}{|c|c|c|c|c|c|}
\hline \multirow[t]{2}{*}{ Sr. no. } & \multirow{2}{*}{$\begin{array}{c}\text { Fertilizer } \\
\text { used }\end{array}$} & \multicolumn{2}{|c|}{ Tracks $/ \mathrm{cm}^{2}$ on leaves } & \multirow[t]{2}{*}{$A M \pm S E^{*}$} & \multirow[t]{2}{*}{$\mathrm{Tcm}^{-2} \mathrm{~d}^{-1}$} \\
\hline & & Top face & Bottom face & & \\
\hline \multirow[t]{2}{*}{1.} & WF & 33 & 49 & $49 \pm 6.7$ & 0.8 \\
\hline & & 49 & 66 & & \\
\hline \multirow[t]{2}{*}{2.} & CDM & 33 & 66 & $58 \pm 11$ & 0.9 \\
\hline & & 49 & 83 & & \\
\hline 3. & DAP & 198 & 215 & $206 \pm 2.6$ & 3.4 \\
\hline 4. & NPK & 133 & 165 & $149 \pm 16$ & 2.5 \\
\hline \multirow[t]{2}{*}{5.} & SSP & 133 & 182 & $149 \pm 15$ & 2.5 \\
\hline & & 116 & 165 & & \\
\hline \multirow[t]{2}{*}{6.} & PF & 165 & 215 & $203 \pm 18$ & 3.4 \\
\hline & & 182 & 248 & & \\
\hline \multirow[t]{2}{*}{7.} & $\mathrm{ZnSO}_{4}$ & 149 & 182 & $174 \pm 10$ & 2.9 \\
\hline & & 165 & 198 & & \\
\hline \multirow[t]{2}{*}{8.} & URA & 116 & 133 & $124 \pm 11$ & 2.1 \\
\hline & & 99 & 149 & & \\
\hline \multirow[t]{2}{*}{9.} & OF & 33 & 38 & $49 \pm 11$ & 0.8 \\
\hline & & 49 & 83 & & \\
\hline
\end{tabular}

${ }^{*} \mathrm{AM}=$ Arithmetic Mean, SE = Standard error $(\sigma / \sqrt{ } N)$, where $\sigma$ is Standard deviation and $\mathrm{N}$ is the no. of observations. were fixed at different parts of each plant i.e. root, stem, leaf and grain (fruit). Similar analysis was carried out after exposure time for each sample under study. The healthy leaves from different samples of plants after regular interval were plucked, dried in an oven at $40^{\circ} \mathrm{C}$ and then sandwiched between two plastic track detectors each with same size $(2 \mathrm{~cm} \times 2 \mathrm{~cm})$ by wrapping a cello tape tightly to record the tracks for alpha radiations emitted from both upper and bottom faces of the leaves. The exposure time of the detectors was 60 days. At the end of exposure time, the detectors were removed and subjected to a chemical etching process in 2.5 $\mathrm{NaOH}$ solution at $60^{\circ} \mathrm{C}$ for one and half hour. The detectors were washed, dried and after that, the tracks caused by alpha radiations emitted from the leaves were counted using optical Olympus microscopes at magnification $400 \mathrm{X}$. The

Table 2 Alpha track densities measured in the leaves of lady's finger plants after $\mathbf{5 0}$ days of plantation

\begin{tabular}{|c|c|c|c|c|c|}
\hline \multirow[t]{2}{*}{ Sr. no. } & \multirow{2}{*}{$\begin{array}{l}\text { Fertilizer } \\
\text { used }\end{array}$} & \multicolumn{2}{|c|}{ Tracks $/ \mathrm{cm}^{2}$ on leaves } & \multirow[t]{2}{*}{$\mathrm{AM} \pm \mathrm{SE}^{*}$} & \multirow[t]{2}{*}{$\mathrm{Tcm}^{-2} \mathrm{~d}^{-1}$} \\
\hline & & Top face & Bottom face & & \\
\hline 1. & WF & 49 & 83 & $66 \pm 17$ & 1.1 \\
\hline 2. & CDM & 66 & 99 & $83 \pm 16$ & 1.4 \\
\hline 3. & DAP & 232 & 265 & $248 \pm 16$ & 4.2 \\
\hline 4. & NPK & 165 & 198 & $182 \pm 16$ & 3.1 \\
\hline 5. & SSP & 149 & 182 & $166 \pm 16$ & 2.7 \\
\hline 6. & PF & 215 & 232 & $224 \pm 8.5$ & 3.7 \\
\hline 7. & $\mathrm{ZnSO}_{4}$ & 165 & 198 & $182 \pm 16$ & 3.1 \\
\hline 8. & URA & 133 & 182 & $157 \pm 24$ & 2.6 \\
\hline 9. & OF & 33 & 66 & $49 \pm 16$ & 0.8 \\
\hline
\end{tabular}

${ }^{*} \mathrm{AM}=$ Arithmetic Mean, SE = Standard error $(\sigma / \sqrt{ } \mathrm{N})$, where $\sigma$ is Standard deviation and $\mathrm{N}$ is the no. of observations. 
Table 3 Alpha track densities measured in the leaves of lady's finger plants after $\mathbf{7 0}$ days of plantation

\begin{tabular}{lccccc}
\hline Sr. no. & $\begin{array}{c}\text { Fertilizer } \\
\text { used }\end{array}$ & \multicolumn{2}{c}{ Tracks/cm on leaves } & AM $\pm \mathbf{S E}^{*}$ & $\mathbf{T c m}^{\mathbf{2}} \mathbf{d}^{\mathbf{1}}$ \\
\cline { 3 - 4 } & Top face & Bottom face & & \\
\hline 1. & WF & 83 & 116 & $99 \pm 16$ & 1.6 \\
2. & $\mathrm{CDM}$ & 133 & 149 & $141 \pm 7.9$ & 2.4 \\
3. & $\mathrm{DAP}$ & 232 & 297 & $265 \pm 32$ & 4.4 \\
4. & $\mathrm{NPK}$ & 198 & 215 & $206 \pm 8.5$ & 3.4 \\
5. & $\mathrm{SSP}$ & 182 & 215 & $198 \pm 16$ & 3.3 \\
6. & $\mathrm{PF}$ & 232 & 281 & $256 \pm 24$ & 4.3 \\
7. & ZnSO & 198 & 232 & $215 \pm 17$ & 3.6 \\
8. & URA & 165 & 198 & $182 \pm 16$ & 3.1 \\
9. & $\mathrm{OF}$ & 49 & 66 & $57 \pm 8.5$ & 0.9 \\
\hline
\end{tabular}

${ }^{*} \mathrm{AM}=$ Arithmetic Mean, $\mathrm{SE}=$ Standard error $(\sigma / \sqrt{ } \mathrm{N})$, where $\sigma$ is Standard deviation and $\mathrm{N}$ is the no. of observations.

alpha track density from the fertilized soil was measured by placing LR-115 of size $2 \times 2 \mathrm{~cm}^{2}$ directly over the soil in the plant pots for 7 days.

\section{Transfer factors}

Transfer factors (TFs), which are the ratios of alpha track densities in plant leaves and soil can be used as an index for the accumulation of trace elements by plants or transfer of elements from soil to plants $[18,19]$. From the observed alpha track density in the plant and in the corresponding soil, the TF values were calculated according to the following equation.

$$
\mathrm{TF}=\frac{\text { Alpha track density in leaves of plant }\left(\mathrm{Tcm}^{-2} \mathrm{~d}^{-1}\right)}{\text { Alpha track density in dry soil }\left(\mathrm{Tcm}^{-2} \mathrm{~d}^{-1}\right)}
$$

\section{Estimation of radon exhalation rates from fertilized soil samples}

The "sealed Canister technique" was used for the measurement of radon concentration and its exhalation rates in soil samples [20]. Samples of soil were collected from different earthen pots. A known amount of oven dried samples (100 gram each) were put in the plastic canister. LR115 type-II plastic track detectors were fixed on the bottom of lid of each canister with tape such that sensitive side of the detector faced the samples. The canisters were tightly closed from the top and sealed. The size of the detectors is $2 \mathrm{~cm} \times 2 \mathrm{~cm}$ and was exposed to samples for 100 days. The detector records the tracks of $\alpha$-particles emitted by radon gas produced through $\alpha$ decay of radium. Radon and its daughters reach an equilibrium concentration after $4 \mathrm{~h}$ and hence equilibrium activity of emergent radon can be obtained from the geometry of "canister" and time of exposure. At the end of the exposure time, the detectors were removed and subjected to a chemical etching and counting process.

Mass exhalation rate ' $E_{M}$ ' is obtained from the following formulae [21,22].

$$
E_{M}=\frac{C V \lambda}{M[T+(1 / \lambda)\{\exp (-\lambda T)-1\}]}\left(\mathrm{Bq} \mathrm{Kg}^{-1} \mathrm{~h}^{-1}\right) \text { for mass exhalation rate }
$$

Where, $E_{M}$ is measured in $\mathrm{Bq} \mathrm{Kg}^{-1} \mathrm{~h}^{-1}$; $\mathrm{C}$ is the Integrated radon exposure as measured by LR-115 solid state nuclear track detectors $\left(\mathrm{Bq} \mathrm{m}{ }^{-3} \mathrm{~h}^{1}\right) ; \mathrm{M}$ is the mass of sample (Kg); V is the volume of air in canister $\left(\mathrm{m}^{3}\right)$; $\mathrm{T}$ is the time of exposure (hrs) and $\lambda$ is the decay constant for radon $\left(\mathrm{h}^{-1}\right)$. The measured track density was converted into radon concentrations using a calibration factor 0.056 tracks. $\mathrm{cm}^{-2} \cdot \mathrm{d}^{-1} / \mathrm{Bq} \cdot \mathrm{m}^{-3}$.

\section{Results and discussion}

Alpha track density measured in plants

During control study carried out on plants grown using different fertilizers, the alpha-track density $\left(\mathrm{Tcm}^{-2}\right)$ was measured in leaves of plants at different interval of time (Figure 2). The variation in alpha track densities was also observed in root, stem, leaf and grain parts of the plants.

Table 4 Alpha track densities measured in the roots, stems, leaves and fruit parts of lady's finger plant after

\begin{tabular}{|c|c|c|c|c|c|c|c|}
\hline \multirow{2}{*}{$\frac{\text { Sr. no. }}{1 .}$} & \multirow{2}{*}{$\frac{\text { Type of fertilizer }}{\text { WF }}$} & \multicolumn{3}{|c|}{ Alpha track densities $\left(\mathrm{Tcm}^{-2} \mathrm{~d}^{-1}\right)$ root lower stem upper stem } & \multirow{2}{*}{$\begin{array}{c}\text { Leaves } \\
1.6\end{array}$} & \multirow{2}{*}{$\frac{\text { Fruit }}{3.1}$} & \multirow{2}{*}{$\begin{array}{r}\mathbf{A M} \pm \mathrm{SE}^{*} \\
3.8 \pm 1.5\end{array}$} \\
\hline & & 9.9 & 2.5 & 1.9 & & & \\
\hline 2. & $\mathrm{CDM}$ & 11.8 & 3.3 & 2.7 & 2.4 & 3.8 & $4.8 \pm 1.7$ \\
\hline 3. & DAP & 20.9 & 5.8 & 4.9 & 4.4 & 6.6 & $8.5 \pm 3.2$ \\
\hline 4. & NPK & 16.3 & 3.8 & 3.6 & 3.4 & 4.7 & $6.3 \pm 2.5$ \\
\hline 5. & SSP & 15.2 & 4.7 & 3.8 & 3.3 & 4.9 & $6.5 \pm 2.2$ \\
\hline 6. & PF & 20.2 & 5.3 & 4.4 & 4.3 & 5.8 & $7.9 \pm 3.1$ \\
\hline 7. & $\mathrm{ZnSO}_{4}$ & 18.5 & 4.7 & 3.8 & 3.6 & 5.3 & $7.2 \pm 2.8$ \\
\hline 8. & URA & 13.3 & 3.8 & 3.3 & 3.1 & 4.7 & $5.7 \pm 1.9$ \\
\hline 9. & OF & 12.9 & 3.1 & 3.1 & 0.9 & 4.2 & $5.2 \pm 1.9$ \\
\hline
\end{tabular}
plantation

${ }^{*} \mathrm{AM}=$ Arithmetic Mean, SE = Standard error $(\sigma / \sqrt{ } \mathrm{N})$, where $\sigma$ is Standard deviation and $\mathrm{N}$ is the no. of observations. 
In case of plants grown using phosphate fertilizers the alpha radioactivity was found to be more compared with other fertilizers. For leaves plucked from the plants after 30 days of plantation of the seeds, it was found that the alpha track densities on the top face of the leaves varied from 33 to $198 \mathrm{~T} \mathrm{~cm}^{-2}$ while at the bottom face these varied from 38 to $248 \mathrm{~T} \mathrm{~cm}^{-2}$ with an average of $49 \pm 11$ to $206 \pm 2.6$ as shown in Table 1. For leaves plucked from the plants after 50 days of plantation of the seeds, it was found that the alpha track densities on the top face of the leaves varied from 33 to $232 \mathrm{~T} \mathrm{~cm}^{-2}$ while at the bottom face these varied from 66 to $265 \mathrm{~T} \mathrm{~cm}^{-2}$ with an average of $49 \pm 16$ to $248 \pm 16$ as shown in Table 2 . For leaves plucked from the plants after 70 days of plantation of the seeds, it was found that the alpha track densities on the top face of the leaves varied from 83 to $232 \mathrm{~T} \mathrm{~cm}^{-2}$ while at the bottom face these varied from 116 to $297 \mathrm{~T} \mathrm{~cm}^{-2}$ with an average of $99 \pm 16$ to $265 \pm$ 32 as shown in Table 3.

The alpha track densities in roots, lower stems, upper stems leaves and fruit parts of lady's finger plant after plantation varied from 9.9 to $20.6 \mathrm{~T} \mathrm{~cm}^{-2} \mathrm{~d}^{-1}, 2.5$ to $5.8 \mathrm{~T} \mathrm{~cm}^{-2} \mathrm{~d}^{-1}, 1.9$ to $4.9 \mathrm{~T} \mathrm{~cm}^{-2} \mathrm{~d}^{-1}, 1.6$ to $4.2 \mathrm{~T} \mathrm{~cm}^{-2} \mathrm{~d}^{-1}$ and 3.1 to $6.6 \mathrm{~T} \mathrm{~cm}^{-2} \mathrm{~d}^{-1}$ with an average of $3.8 \pm 1.5$ to $8.5 \pm 3.2$ as shown in Table 4 . The alpha activity was maximum in root part of the plants and decreased upwards. There is a transportation of radioactive nuclides which may be concentrated near the roots of the plants, where casparian strip; most effective in root of plants and caused blockage of uranium in roots. The
Table 5 Transfer factors for different growing period of leaves of lady's finger plant

\begin{tabular}{|c|c|c|c|c|}
\hline \multirow{2}{*}{$\begin{array}{l}\text { Fertilizer } \\
\text { used }\end{array}$} & \multicolumn{3}{|c|}{ Transfer factors after } & \multirow{2}{*}{$\begin{array}{c}\left(\mathrm{Tcm}^{-2} \mathrm{~d}^{-1}\right) \\
\text { In soil }\end{array}$} \\
\hline & $\begin{array}{l}30 \text { days } \\
\left(\times 10^{-2}\right)\end{array}$ & $\begin{array}{l}50 \text { days } \\
\left(\times 10^{-2}\right)\end{array}$ & $\begin{array}{l}70 \text { days } \\
\left(\times 10^{-2}\right)\end{array}$ & \\
\hline WF & 0.8 & 1.2 & 1.6 & 97 \\
\hline CDM & 0.8 & 1.4 & 2.4 & 103 \\
\hline DAP & 2.1 & 2.6 & 2.7 & 164 \\
\hline NPK & 2.1 & 2.6 & 2.8 & 119 \\
\hline SSP & 2.1 & 2.2 & 2.7 & 123 \\
\hline PF & 2.3 & 2.4 & 2.8 & 153 \\
\hline $\mathrm{ZnSO}_{4}$ & 2.1 & 2.2 & 2.6 & 141 \\
\hline URA & 1.9 & 2.4 & 2.8 & 111 \\
\hline OF & 0.7 & 0.7 & 2.3 & 107 \\
\hline Range & $(0.7-2.3)$ & $(0.7-2.6)$ & $(1.6-2.8)$ & $97-164$ \\
\hline
\end{tabular}

alpha track densities was found to be higher on its bottom face as compared to that on the upper face which may be due to the presence of large number of trichomes at the lower face to which dust particle in the environment with the radon daughter attached, and get stuck. For a given leaf, alpha activity to be higher in the middle portion of the leaf as compared to that in regions near the tip of leaf and the part of leaf near to the stem. This may be due to the higher glandular trichomes in the middle portion of leaves. Also the ventilation in the pheripheral part of leaf is better than that in the middle part of leaf. But it does not affect the alpha track density from leaf

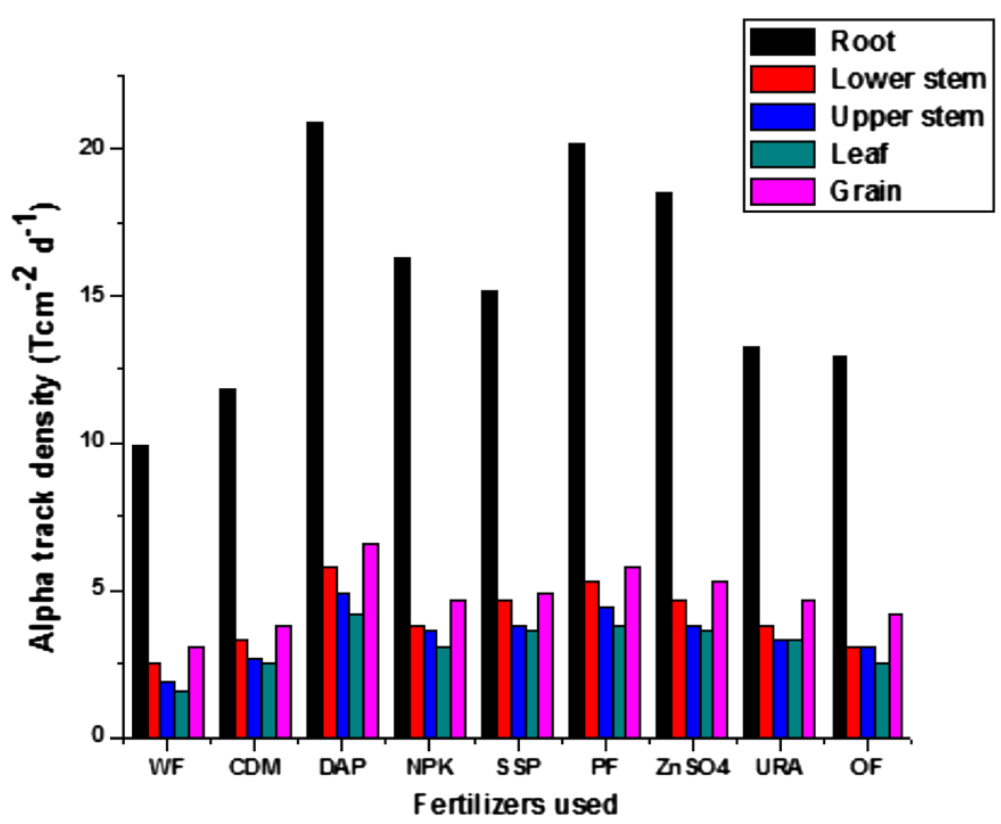

Figure 3 Variation in alpha track densities in roots, lower stem, upper stem, leaf and grain parts of lady's finger plants grown using different fertilizer after $\mathbf{8 0}$ days of plantation. 
part as it is mostly caused by the solid radionuclide rather than radioactive gas radon. The growth observed was better in case of DAP, OF and NPK fertilizers when added before plantation and in case of URA when added few days after the plantation, compared with other fertilizers. The variation in alpha track density per day $\left(\mathrm{Tcm}^{-2} \mathrm{~d}^{-1}\right)$ for different fertilizers has been shown in (Figure 3).

\section{Soil-to-plant transfer factors}

Soil samples were collected from different pots and alpha activity was measured using LR- 115 solid state nuclear track detector. Using the results of alpha track densities in soil and plants the soil-to-plant transfer factors were calculated for different samples using Eq. (1). Transfer factor for 30 days samples was found in the range $(0.7-2.3) \times 10^{-2}$ while for 50 days samples range was $(0.7-2.6) \times 10^{-2}$ (Table 5). Similarly the transfer factors for 70 days samples varied in the range $(1.6-2.8) \times 10^{-2}$ respectively. The alpha track densities in soil varied from $97 \mathrm{Tcm}^{-2} \mathrm{~d}^{-1}$ to $164 \mathrm{Tcm}^{-2} \mathrm{~d}^{-1}$. Using the results of alpha track densities in soil and plants, the soil-to-plant transfer factors were calculated for different leaf samples of the plants. The soil-to-plant transfer factor was also found to increase with addition of some phosphate fertilizers to soil. A positive correlation was observed
Table 6 The measurement of Radon concentration, Mass exhalation rates in some fertilized soil samples used for the present study

\begin{tabular}{|c|c|c|c|}
\hline Sr. no. & $\begin{array}{l}\text { Fertilizer } \\
\text { used soil }\end{array}$ & $\begin{array}{c}\text { Radon concentration } \\
\left(\mathrm{Bqm}^{-3}\right)\end{array}$ & $\begin{array}{l}\text { Radon mass exhalation } \\
\text { rate }\left(\mathrm{mBqKg}^{-1} \mathrm{~h}^{-1}\right)\end{array}$ \\
\hline 1. & WF-Soil & $998 \pm 62$ & $31 \pm 1.9$ \\
\hline 2. & CD-Soil & $1315 \pm 49$ & $41 \pm 1.5$ \\
\hline 3. & DAP-Soil & $2065 \pm 62$ & $64 \pm 1.9$ \\
\hline 4. & NPK-Soil & $1702 \pm 35$ & $53 \pm 1.1$ \\
\hline 5. & SSP-Soil & $2198 \pm 42$ & $68 \pm 1.4$ \\
\hline 6. & PF-Soil & $2088 \pm 46$ & $65 \pm 1.4$ \\
\hline 7. & $\mathrm{ZnSO}_{4}$-Soil & $1782 \pm 46$ & $55 \pm 1.4$ \\
\hline 8. & URA-Soil & $1436 \pm 35$ & $45 \pm 1.1$ \\
\hline 9. & OF-Soil & $1249 \pm 46$ & $38 \pm 1.4$ \\
\hline
\end{tabular}

Mass of the sample $(M)=0.1 \mathrm{Kg}$.

Average volume of air in the can above the sample $(V)=346.18 \times 10^{-6} \mathrm{~m}^{3}$.

between alpha track density of soil and plant samples (Figure 4).

\section{Radon concentration and exhalation rate measurements}

The measured radon concentration and the calculated radon mass exhalation values using Eq. (2) for various samples are presented in Table 6 . The average radon concentration in various samples varied from $998 \pm 62$

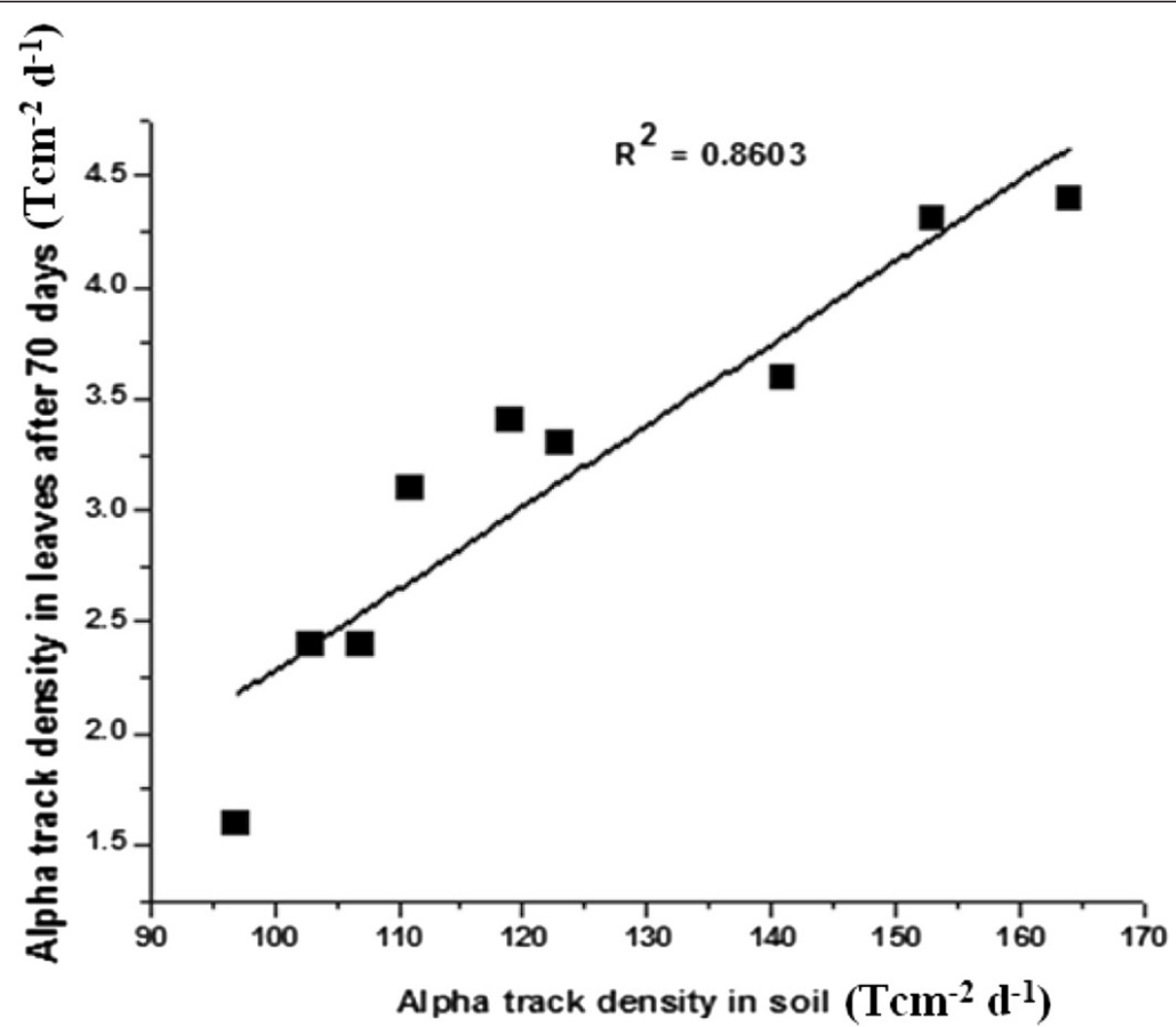

Figure 4 Correlation between alpha track densities for soil and plant leaves after 70 days. 


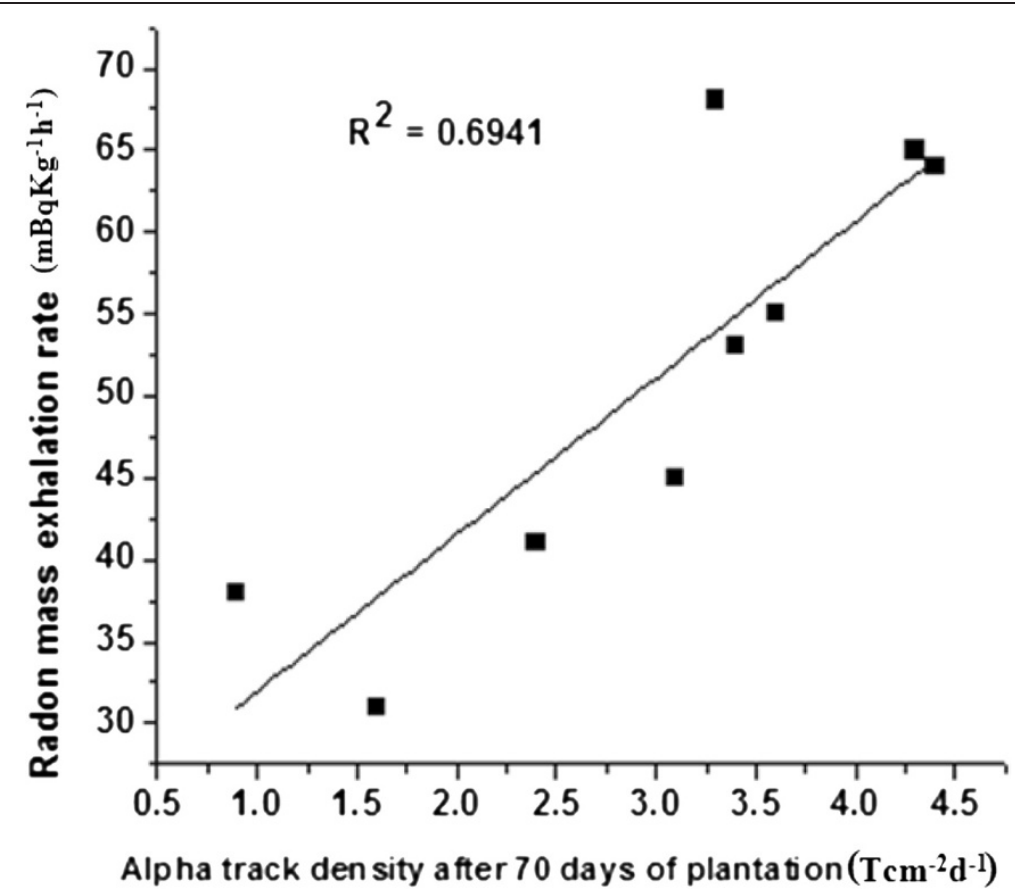

Figure 5 Correlation between alpha track densities in lady's finger plants after 70 days of their plantation and radon mass exhalation rate in fertilized soil samples.

to $2198 \pm 42 \mathrm{Bqm}^{-3}$ while the mass exhalation rates of radon was found to change from $31 \pm 1.9$ to $68 \pm 1.4$ $\mathrm{mBqkg}^{-1} \mathrm{~h}^{-1}$. A positive correlation was observed between the alpha track densities and radon mass exhalation rates with correlation coefficient (0.7864) as shown in (Figure 5). It can be seen from the results that the radon concentration varied appreciably from sample to sample but was found to satisfy the safety criteria except in phosphate fertilizers from radiation safety point of view and hence, these samples do not pose much health hazard problems.

\section{Conclusions}

From present investigation we can conclude that:

- The alpha track densities vary with the nature of fertilizers added to the soil. This may be due to the variation of level in radio nuclides in the fertilizers used for the growth of plants. Transfer factor describes the amount of radionuclides expected to enter a plant from soil.

- The variation in alpha radioactivity with the passage of time of growth due to large absorption of fertilizers by plants. The alpha activity was found to be more in case of potash, D.A.P. fertilizer. This may be due to the fact that the rock mineral apatite, from which phosphate is derived, is rich in uranium and its decay products. The alpha track density was found to be higher on the bottom face as compared to that on the upper face which may be due to the presence of large number of trichomes at the lower face to which dust particle from environment with the radon daughter attached, get stuck.

\section{Competing interests}

The authors declare that they have no competing interests.

\section{Authors' contribution}

The plantation of lady's figures plants were the results of efforts made by both authors. The processing of plant after plantation (drying, chemical etching, counting and exhalation study) was made by corresponding author (PC) and the analysis/interpretation of results were made by co-author (RPC). Both authors have made contribution to the review/finalization of this manuscript and approved the final manuscript.

\section{Acknowledgement}

The authors are thankful to University Grant Commission, New Delhi (Government of India) for providing financial assistance in the terms of major research project.

Received: 23 August 2013 Accepted: 14 April 2014

Published: 22 April 2014

\section{References}

1. Hazrati S, Baghi AN, Sadeghi H, Barak M, Zivari S, Rahimzadeh S: Investigation of natural effective gamma dose rates case study: Ardebil Province in Iran. Iranian J Environ Health Scien \& Eng 2012, 9:1.

2. Mehra R, Kumar S, Sonkawade RG, Singh NP, Badhan K: Analysis of terrestrial naturally occurring radionuclides in soil samples from areas of Sirsa district of Haryana, India using gamma ray spectrometry. Environ Earth Science 2010, 59:1159-1164.

3. Okeji MC, Agwu KK, Idigo FU: Assessment of natural radioactivity in phosphate ore, phosphogypsum and soil samples around a phosphate fertilizer plant in Nigeria. Bull Environ Contam Toxicol 2012, 89:1078-1081.

4. UNSCEAR: United Nations Scientific Committee on the effects of atomic radiation. Effects and risks of ionizing radiations. New York: United Nations; 2000. 
5. Mohanty AK, Sengupta D, Das SK, Saha SK, Van KV: Natural radioactivity and radiation exposure in the high background area at Chhatrapur beach placer deposit of Orissa, India. J Environ Radioact 2004, 75:15-33.

6. Vera Tome F, Blanco Rodri guez MP, Lozano JC: Soil-to-plant transfer factors for natural radionuclides and stable elements in a Mediterranean area. J Environ Radioact 2003, 65:161-175.

7. Ramli AT, Wahab A, Hussein MA, Khalik WA: Environmental ${ }^{238} \mathrm{U}$ and ${ }^{232} \mathrm{Th}$ concentration measurements in an area of high level natural background radiation at Palong, Johor, Malaysia. J Environ Radio 2005, 80:287-304.

8. IAEA: Measurement of radionuclides in food and the environment. A guidebook. Vienna: Technical Reports Series No. 229; 1989.

9. Ghosh D, Deb A, Bera S, Sengupta R, Patra KK: Measurement of natural radioactivity in chemical fertilizer and agricultural soil: evidence of high alpha activity. J Environm Geochem Health 2008, 30:79.

10. Hamilton El: State of the art of trace element determinations in plant matrices: determination of the chemical elements in plant matrices, an overview. Sci Total Environ 1995, 176:3-14.

11. Markose PM: Studies on the Environmental Bahaviour of Radium from Uranium Mill Tailings. PhD thesis, University of Mumbai; 1990.

12. Jibiri NN, Farai IP, Alausa SK: Activity concentration of ${ }^{226} \mathrm{Ra},{ }^{232} \mathrm{Th}$ and ${ }^{40} \mathrm{~K}$ in different food crops from a high background radiation area in Bitsichi, Jos Plateau, Nigeria. Rad Environ Biophy 2007, 46:53-59.

13. Chen $S B$, Zhu YG, Hue QH: Soil to plant transfer of ${ }^{238} \mathrm{U},{ }^{226} \mathrm{Ra}$ and ${ }^{232} \mathrm{Th}$ on a uranium mining-impacted soil from southeastern China. J Environ Radioactiv 2005, 2005(82):223-236.

14. Robinson DS: Food biochemistry and nutritional value. New York, USA: Longman scientific and technical publisher; 1990.

15. lelsch G, Thieblemont D, Labed V, Richon P, Tymen G, Ferry C, Robe MC, Baurbon JC, Bechennec F: Radon ( ${ }^{222} \mathrm{Rn}$ ) level variations on a regional scale influence of the basement trace element $(U, T h)$ geochemistry on radon exhalations rates. J Environ Radioactiv 2001, 53:75-90.

16. Sharma DK, Kumar A, Kumar M, Singh S: Study of uranium, radium and radon exhalation rate in soil samples from some areas of Kangra district, Himachal Pradesh, India using solid-state nuclear track detectors. Rad Measur 2003, 36:363-366.

17. Wiegand J: A guideline for the evaluation of the soil radon potential based on geogenic and anthropogenic parameters. Environ Geol 2001, 40:949-963.

18. Whicker FW, Hinton TG, Orlandini KA, Clark SB: Uptake of natural and anthropogenic actinides in vegetable crops grown on a contaminated lake bed. J Environ Radioactiv 1999, 45:1-12.

19. Yanagisawa K, Muramatsu Y, Kamada H: Tracer experiments on the transfer of technetium from soil to rice and wheat plants. Radioisotopes 1992, 41:397-402.

20. Abu-Jarad F: Application of nuclear track detectors for radon related measurements. Nuclear Tracks and Rad. Measur 1988, 15:525.

21. Mahur AK, Kumar R, Sengupta D, Prasad R: Estimation of radon exhalation rate, natural radioactivity and radiation doses in fly ash samples from Durgapur thermal power plant West Bengal, India. J Environ Radioact 2008, 99:1289-1293.

22. Mahur AK, Kumar R, Mishra M, Sengupta D, Prasad R: An investigation of radon exhalation rate and estimation of radiation doses in coal and fly ash samples. Appl Radiat Isot 2008b, 66:401-406.

\section{doi:10.1186/2052-336X-12-70}

Cite this article as: Chauhan and Chauhan: Variation in alpha radioactivity of plants with the use of different fertilizers and radon measurement in fertilized soil samples. Journal of Environmental Health Science \& Engineering 2014 12:70.

\section{Submit your next manuscript to BioMed Central and take full advantage of:}

- Convenient online submission

- Thorough peer review

- No space constraints or color figure charges

- Immediate publication on acceptance

- Inclusion in PubMed, CAS, Scopus and Google Scholar

- Research which is freely available for redistribution 